\title{
Information needs and use among urban farmers in Kampala City in Uganda
}

\author{
Helen M. Byamugisha, Robert Ikoja-Odongo, George William Nasinyama
}

\begin{abstract}
The paper presents results of a study on information needs and use among urban farmers in Kampala City in Uganda. An information need is recognition that one's knowledge is inadequate to satisfy a goal. Urban farming is characterized by low agricultural production leading to food insecurity. Although urban farming is viewed as an important survival strategy, the information needs of urban farmers in Kampala City are not known. The study used both qualitative and quantitative study design. Methods used were face-to face interview and focus group discussion. Respondents included 380 urban farmers and 36 focus group respondents. Results show that the information needs of the urban farmers were as varied as the heterogeneity of their agricultural enterprises and information was used for different purposes and depended on the type of farming enterprise(s) and activity undertaken. The paper recommends that the dissemination of agricultural information in Kampala City needs to be based on the urban farmers' enterprise groups and their information needs.
\end{abstract}

\section{Introduction}

The fast growth in urban population coupled with rural - urban migration has given rise to food insecurity in Kampala City. As lack of food increases and life for the urban dwellers becomes more complex, urban farming is viewed as one of the alternative survival strategies. Urban farmers are people who practice farming within the city boundaries, including the cultivation of food and cash crops, animal husbandry, forestry, flowers and garden plants production (UNDP 1996). Urban farming is characterized by low agricultural production leading to food insecurity.

\section{Authors}

Helen Byamugisha is the Head of the Books Acquisition Section of Makerere University Library and is a Doctoral candidate; Robert Ikoja-Odongo is Professor of Library and Information Science and George Nasinyama is Associate Professor of Veterinary Medicine, both of Makerere University, Kampala, Uganda.

Email: hbyamugisha@mulib.mak.ac.ug 
Case (2002) suggests that an information need is the recognition that one's knowledge is inadequate to satisfy a goal, while Moore (2002) describes an information need as the lack of appropriate information on which to base choices that could lead to benefits or services that may improve people's well-being. Belkin, Oddy and Brooks (1982) describe an information need as an inadequate state, or an Anomalous State of Knowledge (ASK). Since the information needs of urban farmers in Kampala City are not known, there are no agricultural information services that specifically target these farmers.

Wilson (1981) noted that need is a subjective experience which occurs only in the mind of the person in need, and consequently, is not directly accessible to an observer. He further explained that the experience of need can only be discovered by deduction from behaviour or through the reports of the person in need. Dervin (1977) recognizes limitations in existing research, arguing that the majority of information needs studies have focused upon the library and its activities and has considered the user only in this context. Wilson (1981) hence advises that information need research should focus upon uncovering the facts of everyday life of the people being investigated to understand the needs that exist which press the individual towards information seeking behaviour.

Based on Wilson's advice, Ozowa (1995) studied information needs of small scale farmers in Africa. He found that the information needs of farmers revolve around the resolution of problems such as hazards, weed control, moisture insufficiency, soil fertility, farm credit, labour shortage and soil erosion. He lamented that agricultural information is not integrated with other development programs to address the numerous related problems that face farmers. The author noted that the information provided was exclusively focused on policy makers, researchers, and those who manage policy decisions, with scant attention paid to the information needs of the targeted beneficiaries of the policy decisions, particularly farmers. He warned that non-provision of agricultural information to farmers is a key factor that has greatly limited agricultural development particularly in developing countries. Ozowa (1995) recommended that if the approaches to agricultural development programs are to work, African governments need to take approaches to information dissemination that grow from a clear understanding of what farmers' information needs are.

Earlier, Aina (1991) had studied information for successful agriculture in six farming communities in Nigeria. He found that farmers needed information mainly in the areas of fertilizers, pests and disease control, planting materials, credits and loans. In a related study of the information needs of small scale farmers in Zambia, Kalusopa (2005) found the most important information needs of small-scale farmers to be farm management, diary management, poultry equipment and technology. He stressed that although agricultural development activities are based on the utilization of information, the role of information in agricultural development had not received sufficient attention by the Government of Zambia. The supply of information in the agricultural sector was scattered, poorly developed and unfocused. Kalusopa (2005) concluded that in order for agriculture to improve, there was need to have a well organized and functional integrated information delivery system supported by efficient national collaboration programs. 
Wesseler (2002) intimated that farmers' information needs pertain to the production and initial processing of farm products, and to the market (prices, quantity, quality, mandatory norms, etc.), natural resources and their management. The author advised that many limitations such as illiteracy, poor communication networks (deficient or non-existent infrastructure), and inappropriate support from service providers must be lifted in order to begin to meet these information needs efficiently.

Information use, on the other hand, is a behaviour that consists of the physical and mental acts involved in incorporating the information found into the person's existing knowledge base (Marchionini, 2001). Wilson (1981) pointed out that one of the problems with information use is that information processing is as subjective as information need, and like information need, is not observable since it takes place in the mind of the individual. Wilson and Walsh (1996) proposed eight general categories which describe how people use information. To them, information may be used to develop a context; understand a particular situation; know what and how to do something; get the facts about something; confirm another item of information; project future events; motivate or sustain personal involvement; develop relationships, enhance status, reputation or personal fulfillment.

Although Savolainen (1994) acknowledges that the use of information has not been successfully studied, results of research in information use in other disciplines (e.g. artificial intelligence, cognitive research in learning, memory and thinking) indicate that the first characteristic to be noted about users is that the number of those who have need of information far exceeds those who actually use it. Therefore, it can be hypothesised that if the information needs of urban farmers in Kampala district were known and if the farmers had access to and used agricultural information, they would make the best use of resources at their disposal thereby improving urban food security and reducing urban poverty.

\section{Methodology}

This research adopted a mixed method approach using a dominant quantitative and less-dominant qualitative design. The mixed methods approach aims to overcome the weaknesses that are often experienced in single method studies, allows the strengths and weaknesses of each technique to be addressed and arguably produces more convincing research findings (Creswell, 2009). Both purposive and simple random sampling methods were used to select the study areas and the respondents. The three study Divisions namely Kawempe, Nakawa and Rubaga were selected using a purposive method. A simple random sampling method (Lottery method) was used to select nine parishes (three from each Division) while a systematic sampling method using random numbers was used to select 380 urban farming households from all the nine parishes. In addition, a purposive sampling strategy was employed to select 36 focus group respondents from nine parishes from the three study Divisions.

Methodological Triangulation (the use of multiple methods to study a single problem) was employed to collect data. Face-to-face interview and focus group discussion were hence the methods used to collect data on urban farmers' 
information needs and information use. A structured interview guide and a focus group interview schedule were the instruments used to collect data. Data analysis for the quantitative data was done using the Statistical Package for the Social Sciences (SPSS) software. For the qualitative data, analysis followed the guidelines laid out by Krueger and Casey (2000). The strategy involved content analysis that included examining transcripts, categorizing responses and analyzing themes that emerged in the data. Chunks or units of data, a process referred to as 'unitizing' the data (Guba and Lincoln, 1985) were identified; categories were developed according to the themes of the study, namely information needs and use. Some qualitative interviews responses based on verbatim recordings (translated from vernacular to English) are quoted in italics and are given in the findings.

\section{Findings}

\subsection{Urban Farmers' Agricultural Information Needs}

The study sought to establish the information needs of the urban farmers. The results in Table 1 show that of the 374 farmers interviewed, the greatest need for information was about markets and prices (62.3\%). This was followed by information needs on improving farming practices (59.6\%), pest control and management $(51.9 \%)$ as well as nutrition and fertilizers $(50.8 \%)$. Just over one third of farmers wanted information on disease resistant animals $(42.5 \%)$, disease resistant crops (39.6\%) and better animal breeds (39.6\%), while information about improved seed varieties $(34.2 \%)$, soil management $(31.3 \%)$, and weather and environment management $(30.2 \%)$ received a number of mentions. The farmers showed less need for information about safe water and weather (5.9\%) probably because there are many sources of safe water in Kampala City due to the presence of the National Water and Sewerage.

A Chi-square test for independency was used to test for the relationship between the types of information need and both gender and farming enterprise. While there was no significant relationship between information need and gender (with the exception of information needs concerning improved farming practices), the results show that there was a highly significant relationship between farmers' information needs and the type of urban farming enterprise undertaken. For example, the farmers engaged in animal production showed a higher need for information on markets and prices $(73.0 \%)$ than those involved in crop production $(47.0 \%)$. Conversely, the crop producing farmers showed a higher need for information on improved farming practices $(74.4 \%)$ than those who farmed animals $(33.6 \%)$.

Responses from the three focus group discussions were not divergent although they additionally expressed a need for information on land management and the right seasons for planting crops. The farmers needed information about extension services such as veterinary services and on the monitoring of their agricultural activities by the extension personnel. The respondents indicated a need for information on how to plan their agricultural activities, saying, "it is through this information that one can plan for the activity that he wants to carry out". The farmers expressed a need for information on how to effectively utilize the little 
land they occupied. Both male and female respondents argued that they spent a lot of money buying expensive animal drugs and feeds.

"We want to know the right animal drugs or vaccines to use because in some animal drug shops, people sell expired animal drugs while others sell drugs that are no longer recommended for use".

\begin{tabular}{|c|c|c|c|c|c|c|c|c|}
\hline \multirow[b]{2}{*}{$\begin{array}{l}\text { Type of information } \\
(n=374)\end{array}$} & \multicolumn{2}{|c|}{ Gender } & \multirow[b]{2}{*}{$\begin{array}{l}\text { p- } \\
\text { value }\end{array}$} & \multicolumn{3}{|c|}{ Farming type } & \multirow[b]{2}{*}{$\begin{array}{l}\text { p- } \\
\text { value }\end{array}$} & \multirow[b]{2}{*}{$\begin{array}{l}\text { All } \\
(\%)\end{array}$} \\
\hline & $\begin{array}{l}\text { Male } \\
(\%)\end{array}$ & $\begin{array}{l}\text { Female } \\
(\%)\end{array}$ & & $\begin{array}{l}\text { Crop } \\
(\%)\end{array}$ & $\begin{array}{l}\text { Animal } \\
(\%)\end{array}$ & $\begin{array}{l}\text { Both } \\
(\%)\end{array}$ & & \\
\hline Markets and prices & 64.1 & 61.2 & 0.577 & 47.0 & 73.0 & 65.9 & 0.000 & 62.3 \\
\hline Credit Facilities & 37.3 & 32.3 & 0.323 & 29.1 & 40.2 & 33.3 & 0.188 & 34.2 \\
\hline $\begin{array}{l}\text { Improved farming } \\
\text { practices }\end{array}$ & 52.1 & 64.2 & 0.021 & 74.4 & 33.6 & 70.4 & 0.000 & 59.6 \\
\hline Nutrition & 25.4 & 30.6 & 0.275 & 12.8 & 33.6 & 37.8 & 0.000 & 28.6 \\
\hline Fertilizers & 17.6 & 25.0 & 0.095 & 36.8 & 2.5 & 7.4 & 0.000 & 22.2 \\
\hline $\begin{array}{l}\text { Policies/laws related to } \\
\text { urban farming }\end{array}$ & 12.7 & 16.8 & 0.280 & 13.7 & 11.5 & 20.0 & 0.140 & 15.2 \\
\hline $\begin{array}{l}\text { Pest } \\
\text { control/management }\end{array}$ & 50.0 & 53.0 & 0.571 & 58.1 & 38.5 & 58.5 & 0.002 & 51.9 \\
\hline Land availability & 12.0 & 14.2 & 0.535 & 19.7 & 6.6 & 14.1 & 0.011 & 13.4 \\
\hline Health & 23.9 & 20.3 & 0.401 & 9.4 & 30.3 & 24.4 & 0.000 & 21.7 \\
\hline $\begin{array}{l}\text { Environment } \\
\text { management }\end{array}$ & 26.8 & 22.8 & 0.392 & 29.1 & 16.4 & 27.4 & 0.043 & 30.2 \\
\hline Soil management & 29.6 & 32.3 & 0.578 & 46.2 & 5.7 & 41.5 & 0.000 & 31.3 \\
\hline Weather & 6.3 & 5.6 & 0.770 & 6.8 & 2.5 & 8.1 & 0.134 & 5.9 \\
\hline Harvesting and storage & 6.3 & 5.6 & 0.278 & 10.3 & 0.8 & 14.1 & 0.001 & 8.6 \\
\hline Safe water & 7.7 & 4.7 & 0.231 & 1.7 & 5.7 & 9.6 & 0.029 & 5.9 \\
\hline Improved seed varieties & 31.0 & 36.2 & 0.302 & 47.9 & 6.6 & 47.4 & 0.000 & 34.2 \\
\hline Better animal breeds & 38.0 & 40.5 & 0.633 & 6.0 & 55.7 & 54.1 & 0.000 & 39.6 \\
\hline Disease resistant crops & 34.5 & 42.7 & 0.117 & 56.4 & 7.4 & 54.1 & 0.000 & 39.6 \\
\hline $\begin{array}{l}\text { Disease resistant } \\
\text { animals }\end{array}$ & 38.3 & 45.3 & 0.170 & 7.7 & 59.0 & 7.8 & 0.000 & 42.5 \\
\hline $\begin{array}{l}\text { Total number of } \\
\text { respondents }\end{array}$ & 142 & 232 & & 117 & 122 & 135 & & 374 \\
\hline
\end{tabular}

Table 1: Types of information needed by urban farmers 
They unanimously expressed need for information on how to build animal shelters, and on how to make animal drugs and animal feeds from locally available materials. The farmers further said that they needed information on seasonal changes, the right crops and when to plant them.

The indication was that urban farmers' information needs were as varied as the heterogeneity of their farming enterprises, activities or tasks. The findings are in line with Ozowa (1995) who observed that the information needs of small scale farmers revolve around the resolution of problems related to pests hazards, weed control, soil fertility, farm credit and soil erosion. As Ozowa (1995) emphasizes, no one can categorically claim to know all the information needs of urban farmers especially in an information dependent sector like agriculture where there are new and rather complex problems facing farmers every day. However, the findings of this study indicate that it may be possible to identify significant groups of urban farmers who share common information needs. Therefore, the dissemination of agricultural information should be based on the different urban farmers' enterprise groups and those groups' information needs.

The farmers were next asked to narrate the situations in which they had experienced a need for agricultural information. Varied responses were given. The results show that of the 364 farmers who responded, 54.4\% needed information when animals were sick and $40.9 \%$ of farmers identified a need for information when yields were low (see Table 2). A Chi-square test for independency was again used to test for the relationship between the situations in which information needs arose and both gender and type of farming enterprise. While there was no significant correlation between gender and the situation in which information needs arose, there was a high significant relationship between the situations in which farmers' information needs arose and category of farming enterprise (represented by $\mathrm{p}=0.000$ and 0.004 ). This is not unexpected since the situations described are mostly applicable to either crop farmers or to animal farmers but not both (e.g. 'before planting and want to know about rains' or 'when my animals are sick').

Members of the three focus groups had similar views but in addition mentioned that the farmers needed agricultural information during harvesting and marketing of the produce. However, the focus group respondents unanimously insisted that they needed the information all the time as long as farming activities were taking place. The indication was that rather than gender, urban farmers need for information was specific to the problem situations they found themselves in and mainly depended on the type of farming enterprise.

The findings agree with van Lill (2000) who argues that a crucial generator or source of information need is the situation which causes the need. This author pointed out that the situational approach places emphasis not so much on the users, but rather, on the problem situations in which the users find themselves. This therefore implies that information providers in Kampala City need to have knowledge of the different farming enterprises that the farmers engage in and the situations in which their information needs may arise. 


\begin{tabular}{|c|c|c|c|c|c|c|c|c|}
\hline \multirow[b]{2}{*}{ Situations $(n=364)$} & \multicolumn{2}{|c|}{ Gender } & \multirow[b]{2}{*}{$\begin{array}{l}\text { p- } \\
\text { value }\end{array}$} & \multicolumn{3}{|c|}{ Farming Type } & \multirow[b]{2}{*}{$\begin{array}{l}\text { p- } \\
\text { value }\end{array}$} & \multirow[b]{2}{*}{$\begin{array}{l}\text { Total } \\
(\%)\end{array}$} \\
\hline & $\begin{array}{l}\text { Male } \\
(\%)\end{array}$ & $\begin{array}{l}\text { Female } \\
\%)\end{array}$ & & $\begin{array}{l}\text { Crop } \\
(\%)\end{array}$ & $\begin{array}{l}\text { Animal } \\
(\%)\end{array}$ & $\begin{array}{l}\text { Both } \\
(\%)\end{array}$ & & \\
\hline $\begin{array}{l}\text { When I want land for } \\
\text { farming }\end{array}$ & 28.7 & 28.1 & .901 & 42.9 & 10.2 & 32.1 & .000 & 28.3 \\
\hline $\begin{array}{l}\text { Before planting, and } \\
\text { want to know about rains }\end{array}$ & 26.5 & 36.80 & .042 & 54.5 & 5.1 & 33.6 & .000 & 33.0 \\
\hline $\begin{array}{l}\text { When my animals are } \\
\text { sick }\end{array}$ & 54.4 & 54.4 & .996 & 6.2 & 77.1 & 74.6 & .000 & 54.4 \\
\hline When I get low yields & 36.8 & 43.4 & .212 & 59.8 & 14.4 & 48.5 & .000 & 40.9 \\
\hline When I need fertilizers & 22.8 & 21.5 & .772 & 31.2 & 3.4 & 30.6 & .000 & 22.0 \\
\hline $\begin{array}{l}\text { When I want solution for } \\
\text { crop disease }\end{array}$ & 33.8 & 40.8 & .186 & 54.5 & 5.9 & 53.0 & .000 & 38.2 \\
\hline $\begin{array}{l}\text { When I want to start } \\
\text { rearing chicken, pigs or } \\
\text { cattle }\end{array}$ & 29.4 & 23.7 & .227 & 4.5 & 42.4 & 29.1 & .000 & 25.8 \\
\hline $\begin{array}{l}\text { When I want to sell some } \\
\text { produce for money }\end{array}$ & 31.6 & 30.7 & .855 & 19.6 & 39.8 & 32.8 & .004 & 31.0 \\
\hline $\begin{array}{l}\text { Total number of } \\
\text { respondents }\end{array}$ & 136 & 228 & & 118 & 121 & 134 & & 364 \\
\hline
\end{tabular}

Table 2: Situations in which urban farmers needed agricultural information

\subsection{How Agricultural Information was used}

The farmers were asked to describe how they used the agricultural information they received. Table 3 shows that information was mainly used in controlling animal diseases $(51.5 \%)$ followed by controlling crop diseases $(48.2 \%)$. The findings show that except for getting access to markets $(\mathrm{p}=0.003)$, there was no significant difference in information use between female and male urban farmers. However, there was a strong correlation between information use and the type of farming enterprise as reflected by the p-value in table 3 below.

Although one would have expected higher use of information among farmers with higher levels of education, there was no significant difference in information use among the farmers with different education levels except for knowing how to get access to credit $(\mathrm{p}=.012)$ and having knowledge of urban farming laws $(\mathrm{p}=.003)$. The indication is that while agricultural information was used for different purposes, the level of information use per activity varied. These responses were in line with Wilson and Walsh's (1996) information use categories described above. In this model the significance and role of agricultural information were conceptualized as the value urban farmers attributed to information. This led to various actions that put the knowledge acquired into practice or applied the information for decision making. 


\begin{tabular}{|c|c|c|c|c|c|c|c|c|c|c|c|c|c|c|}
\hline \multirow[b]{2}{*}{$\begin{array}{l}\text { How information is } \\
\text { used }(n=361)\end{array}$} & \multicolumn{2}{|c|}{ Gender } & \multirow[b]{2}{*}{ 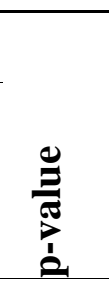 } & \multicolumn{3}{|c|}{ Farming type } & \multirow[b]{2}{*}{ 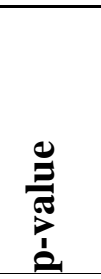 } & \multicolumn{5}{|c|}{ Education level } & \multirow[b]{2}{*}{ 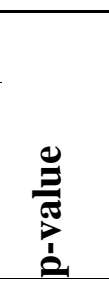 } & \multirow[b]{2}{*}{ 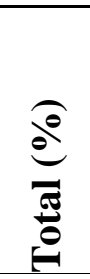 } \\
\hline & 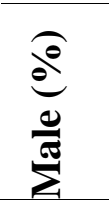 & 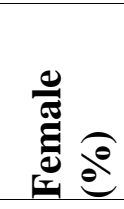 & & อั่ & 苞 & 胥 & & : & 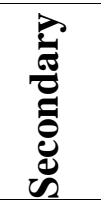 & $\stackrel{\overparen{E}}{\overparen{E}}$ & 毵 & $\stackrel{\Xi}{\tilde{z}}$ & & \\
\hline $\begin{array}{l}\text { Get access to markets } \\
\text { for output }\end{array}$ & 54.0 & 37.8 & .003 & 36.0 & 51.3 & 44.3 & .067 & 41.9 & 51.7 & 38.3 & 55.6 & 26.9 & .067 & 44.0 \\
\hline $\begin{array}{l}\text { Learnt how to apply } \\
\text { manure or fertilizers }\end{array}$ & 31.7 & 35.6 & .443 & 45.9 & 14.3 & 42.0 & .000 & 32.3 & 37.6 & 26.1 & 55.6 & 46.2 & .103 & 34.1 \\
\hline $\begin{array}{l}\text { Learnt how to control } \\
\text { crop diseases }\end{array}$ & 42.4 & 51.8 & .083 & 66.7 & 10.9 & 66.4 & .000 & 41.9 & 47.0 & 53.0 & 77.8 & 38.5 & .179 & 48.2 \\
\hline $\begin{array}{l}\text { Learnt how to control } \\
\text { animal diseases }\end{array}$ & 48.9 & 53.2 & .434 & 7.2 & 77.3 & 65.6 & .000 & 51.6 & 55.0 & 50.4 & 33.3 & 42.3 & .580 & 51.5 \\
\hline $\begin{array}{l}\text { Increased agricultural } \\
\text { production }\end{array}$ & 48.9 & 47.3 & .764 & 50.5 & 28.6 & 63.4 & .000 & 56.5 & 43.6 & 49.6 & 44.4 & 46.2 & .539 & 47.9 \\
\hline $\begin{array}{l}\text { Learnt how to access } \\
\text { credit facilities }\end{array}$ & 13.7 & 16.2 & .512 & 9.0 & 13.4 & 22.1 & .015 & 11.3 & 22.8 & 7.8 & 22.2 & 11.5 & .012 & 15.2 \\
\hline $\begin{array}{l}\text { Have knowledge about } \\
\text { availability of urban } \\
\text { farm land }\end{array}$ & 10.1 & 9.5 & .848 & 5.4 & 5.0 & 17.6 & .001 & 6.5 & 10.1 & 8.7 & 11.1 & 19.2 & .460 & 9.7 \\
\hline $\begin{array}{l}\text { Have knowledge about } \\
\text { urban farming laws }\end{array}$ & 36.0 & 26.1 & .047 & 28.8 & 31.9 & 29.0 & .842 & 41.9 & 33.6 & 21.6 & 11.1 & 3.8 & .003 & 29.9 \\
\hline $\begin{array}{l}\text { Total number of } \\
\text { respondents }\end{array}$ & 139 & 222 & & 111 & 119 & 131 & & 62 & 149 & 115 & 9 & 26 & & 361 \\
\hline
\end{tabular}

Table 3: Use of agricultural information 


\begin{tabular}{|c|c|c|c|c|c|c|c|c|c|c|c|c|c|c|}
\hline \multirow[b]{2}{*}{$\begin{array}{l}\text { The benefits accrued } \\
\text { from utilizing the } \\
\text { information }(n=374)\end{array}$} & \multicolumn{2}{|c|}{ Gender } & \multirow[b]{2}{*}{ 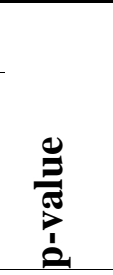 } & \multicolumn{3}{|c|}{ Farming type } & \multirow[b]{2}{*}{ 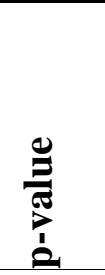 } & \multicolumn{5}{|c|}{ Education level } & \multirow[b]{2}{*}{ 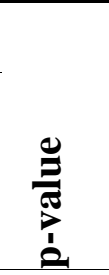 } & \multirow[b]{2}{*}{$\underbrace{\frac{\sigma}{0}}_{\frac{\sigma}{2}}$} \\
\hline & $\underbrace{\frac{0}{a}}_{\frac{0}{a}}$ & 窇 & & ชั่ & 焉 & 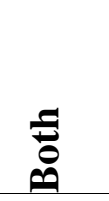 & & : & 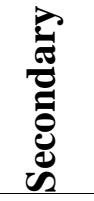 & $\stackrel{\overparen{E}}{\stackrel{E}{E}}$ & 莺 & $\stackrel{\ddot{Z}}{Z}$ & & \\
\hline $\begin{array}{l}\text { Have enough food for } \\
\text { my family }\end{array}$ & 54.9 & 60.3 & .303 & 68.4 & 29.5 & 75.6 & .000 & 60.9 & 62.9 & 53.3 & 36.4 & 57.1 & .296 & 58.3 \\
\hline Sell excess for income & 56.3 & 45.7 & .046 & 29.1 & 61.5 & 57.0 & .000 & 46.9 & 55.6 & 49.2 & 45.5 & 28.6 & .115 & 49.7 \\
\hline $\begin{array}{l}\text { Farming keeps me } \\
\text { busy since I do not } \\
\text { have other job }\end{array}$ & 19.0 & 30.2 & .017 & 24.8 & 18.9 & 33.3 & .029 & 15.6 & 27.8 & 28.3 & 18.2 & 32.1 & .279 & 25.9 \\
\hline $\begin{array}{l}\text { Total number of } \\
\text { respondents }\end{array}$ & 142 & 232 & & 117 & 122 & 135 & & 64 & 151 & 120 & 11 & 28 & & 374 \\
\hline
\end{tabular}

Table 4: The benefits accrued from utilizing agricultural information 


\subsection{Benefits that accrued from using agricultural information}

The impact of information usage was judged by the benefits that accrued. Table 4 shows that having enough food for the family (58.3\%) was the most frequent benefit, followed by selling excess for income (49.7\%). The views from the focus group discussions also emphasized that the major benefit from using agricultural information was improved agricultural production:

"I had one cow but when I got information from a fellow farmer about cross-bred cows, I used the information. As a result of this information, I multiplied my cows and I now have 8 cows" (male FGD participant, Nakawa Division).

A female participant from Kawempe Division said:
"I got and used information on how to keep eggs and then sell them at once. As a result, I now sell many trays and have improved my standards of living".

The implication is that information use is as varied as the farmers' farming enterprises and needs. This finding tallies with Meho and Hass (2001) who believe that information use is an indicator of information needs and a behaviour that leads an individual to the use of information in order to meet his/her information needs. But as Mwala (1997) pointed out, the use of information may also have varied as a result of the value urban farmers attached to information, the characteristics of the individual urban farmer seeking information, social and organizational factors as well as urban farming tasks' requirements.

The respondents were asked to describe the level of satisfaction they derived from using the agricultural information they obtained. The aim was to establish whether the information received satisfied the farmers' needs. Interestingly, slightly over half of the respondents derived partial satisfaction (50.6\%) as compared to $49.4 \%$ of the respondents who reported full satisfaction. Moreover, the survey data indicates that in cases where the farmers were not satisfied with the information obtained, they started information search all over again. Rational choice theory provides a framework for understanding why individuals decide how much effort is needed to find information in order to accomplish their objectives. The theory posits that when faced with several courses of action, people usually do what they believe is likely to have the best overall outcome (Scott, 2006). Actors assess costs and benefits according to their own preferences, value and utilities and then choose an alternative that promises to maximize the benefits relative to the effort or cost required (Prabha at al., 2007). However, in real life situations, urban farmers may not have had at their disposal the full range of all possible choices with which to assess and compare the benefits of each choice in relation to the effort or cost. Therefore, the premise of rational choice theory has been challenged and debated widely by scholars. For example, Simon (1995) proposed the concept of satisficing behaviour, recognizing that in many situations it is neither possible to know the entire spectrum of options, nor is it possible to compare the benefits each option may offer. In practice, satisficing translates into judgment that the information is good enough to satisfy a need even though the full cost-benefit analysis was not performed. According to Schmid (2004), when 
individuals satisfice, they compare the benefits of obtaining more information against the additional cost and effort of continuing to search. Theoretically, decision makers consider all potential alternatives until the optimal solution emerges (Stroh et al., 2002). However, such an exhaustive analysis would require additional time and expenditure which information seekers, including urban farmers, must weigh against the likelihood that they will find additional information of sufficient value to offset the cost of continued searching. The consequences of putting time and effort into finding optimal solutions can be costly. Users may hence satisfice their need for information based on what they are able to find and thus stop looking for more information. Prabha (2007) noted that users may also stop looking for information prematurely if the information systems are difficult or unusable. Therefore, the very abundance of agricultural information makes it crucial for urban farmers in Kampala City to decide on what information would be enough to satisfy their needs although like Stroh et al., (2002) advised, the farmers must be willing to forgo the best solution in favour of one that is acceptable.

\subsection{Information Transfer}

A final question aimed to find out whether the agricultural information obtained was shared with other people. Although the value of information is subjective, the results show that information obtained was transferred to other people. Table 5 shows that out of 326 farmers who responded to this question, the majority of them transferred information to neighbours $(71.8 \%)$ and approximately half passed it on to family members not in the same household ('other family members', $47.2 \%)$. The lowest proportion of farmers (6.7\%) transferred information to local leaders, probably because the farmers instead expected to receive information from these people. The results also show that neither gender, farming enterprises nor education level influenced the way urban farmers shared information. Views from FGDs show that information obtained was mainly transferred to fellow farmers who were involved in similar farming activities:

"We exchange information with fellow farmers because they are the immediate people to help us before looking for the LC's who are always out of their offices. One time I went to the animal drug shops and I was given expired drugs and when I used the drugs, my animal died. Because of that, fellow farmers are more helpful".

Some of the people who had encountered problems in accessing agricultural information in one way were able to access and utilize it in another. The fact that urban farmers shared information with other people is recognition that information flow among them is rarely one way. This confirms the findings of Marcella and Baxter (2005) who observed that transferring information to other people is a considerable break from the linear information provider / information user picture which previously dominated the perceptions of the information professions. 


\begin{tabular}{|c|c|c|c|c|c|c|c|c|c|c|c|c|c|c|}
\hline \multirow[b]{2}{*}{$\begin{array}{l}\text { To whom } \\
\text { information is } \\
\text { transferred }(n=326)\end{array}$} & \multicolumn{2}{|c|}{ Gender } & \multirow[b]{2}{*}{ 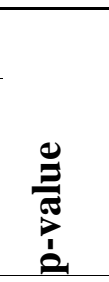 } & \multicolumn{3}{|c|}{ Farming type } & \multirow[b]{2}{*}{ 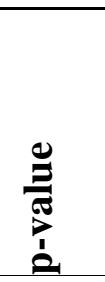 } & \multicolumn{5}{|c|}{ Education level } & \multirow[b]{2}{*}{ 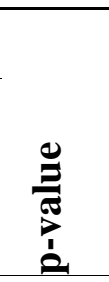 } & \multirow[b]{2}{*}{$\underbrace{\frac{3}{0}}_{\frac{\sigma}{0}}$} \\
\hline & $\underbrace{\underbrace{0}}_{\frac{0}{\pi}}$ & 窇 & & 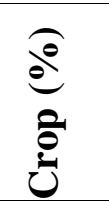 & 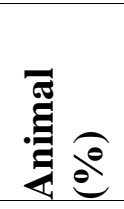 & $\underbrace{\infty}_{0}$ & & : & 苞 & 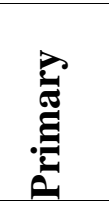 & 昰 & Ż & & \\
\hline $\begin{array}{l}\text { My household } \\
\text { members }\end{array}$ & 28.1 & 18.2 & .035 & 22.7 & 25.5 & 18.5 & .440 & 30.4 & 19.7 & 21.6 & 18.2 & 20.0 & .585 & 22.1 \\
\hline Other family members & 46.9 & 47.5 & .916 & 49.5 & 41.8 & 50.4 & .372 & 37.5 & 51.1 & 52.9 & 27.3 & 30.0 & .077 & 47.2 \\
\hline My neighbours & 68.8 & 73.7 & .329 & 70.1 & 68.2 & 76.5 & .345 & 71.4 & 70.8 & 75.5 & 45.5 & 75.0 & .328 & 71.8 \\
\hline $\begin{array}{l}\text { Farmer group } \\
\text { members }\end{array}$ & 25.8 & 23.2 & .600 & 16.5 & 20.9 & 33.6 & .009 & 14.3 & 29.2 & 22.5 & 27.3 & 25.0 & .280 & 24.2 \\
\hline $\begin{array}{l}\text { People at seminars, } \\
\text { conferences and } \\
\text { workshops }\end{array}$ & 25.0 & 30.8 & .257 & 25.8 & 22.7 & 36.1 & .062 & 33.9 & 33.6 & 22.5 & 27.3 & 10.0 & .104 & 28.5 \\
\hline Extension link farmers & 10.2 & 12.1 & .585 & 9.3 & 8.2 & 16.0 & .133 & 5.4 & 13.9 & 11.8 & .0 & 15.0 & .336 & 11.3 \\
\hline Local leaders & 7.0 & 6.6 & .870 & 3.1 & 6.4 & 10.1 & .123 & 3.6 & 10.2 & 5.9 & .0 & .0 & .208 & 6.7 \\
\hline $\begin{array}{l}\text { Total number of } \\
\text { respondents }\end{array}$ & 128 & 198 & & 97 & 110 & 119 & & 56 & 137 & 102 & 11 & 20 & & 326 \\
\hline
\end{tabular}

Table 5: Transfer of agricultural information to others 


\section{Conclusion}

Urban farmers' information needs were context-specific and as varied as the heterogeneity of the farming enterprises and activities or tasks. As Ozowa (1995) emphasizes, no one can claim to know all the information needs of urban farmers in Kampala City especially in an information dependent sector like agriculture where there are new and complex problems facing farmers every day. However, it is possible to identify significant groups of urban farmers who share common information needs. While farmers use information for different purposes, the level of use depends on the farming enterprise(s) and activity. But as Mwala (1997) points out, the use of information may also vary due to the value that urban farmers attach to information, the characteristics of the individual urban farmer seeking for information as well as social and organizational factors. Given the results of this study it is recommended that the dissemination of agricultural information to urban farmers in Kampala City should be based on the different urban farmers' enterprise groups and their information needs.

\section{References}

Aina, L.O. (1991) Information for successful agriculture, World Libraries [online], 2(1). URL: http://www.worlib.org/vol02no1/aina_v02n1.shtml [accessed 05.12.10].

Belkin, N.J. Oddy, R.N., and Brooks, H.M. (1982) ASK for information retrieval: Part I. Background and theory. Journal of Documentation, 38(2), 61-71.

Case, D. (2002) Looking for information: survey of research on information seeking, needs, and behaviour. San Diego: Academic Press.

Dervin, B. and Nilan, M. S. (1986) Information needs and uses, Annual Review of Information Science and Technology, 21, 3-33.

Guba, E.G., and Lincoln, Y.S. (1989) Fourth generation evaluation. Newbury Park, CA: Sage.

Kalusopa, T. (2005) The challenges of utilizing information communication technologies for the small-scale farmers in Zambia, Library Hi Tech, 23(3), 414424.

Kruger, R. A., and Casey, M. A. (2000) Focus groups: A practical guide for applied research. $3^{\text {rd }}$ Ed. Thousand Oaks, CA: Sage Publications.

Marcella, R., Baxter, G., Moore, N. (2002) Theoretical and methodological approaches to the study of information need in the context of the impact of new information and communications technologies on the communication of parliamentary information, Journal of Documentation, 58(2), 185-210.

Marchionini, G. (1995) Information seeking in the electronic environments, Cambridge: Cambridge University Press.

Mwala, K. S. (1997) Using the library for problem solving in African agriculture. Information Development, 13(3), 132-134. 
Ozowa V. N. (1995) Information Needs of Small Scale Farmers in Africa: The Nigerian example. Quarterly Bulletin of the International Association of Agricultural Information Specialists, IAALD/CABI, 40(1).

Reprinted at URL:

http://www.worldbank.org/html/cgiar/newsletter/june97/9nigeria.html [accessed 05.12.10].

Prabha, C., Connaway, L.S., Olszewski, L., and Jenkins, L.R. (2007) What is enough? Satisfying information needs. Journal of Documentation, 63(1), 74-89.

Savolainen, R. (1999) Everyday life information-seeking: Approaching information-seeking in the context of way of life. Library and Information Science Research, 17, 259-294.

Schmid, A. A. (2004) Conflict and cooperation: Institutional and behavioural economics. Malden, MA: Wiley-Blackwell.

Scott, J. (2006) Rational choice theory. In: Browning, G., Halcli,A. And Webster, F. (eds.) Understanding contemporary society: theories of the present. London: Sage Publications. Also available from URL: http://privatewww.essex.ac.uk/ scottj/socscot7.htm [accessed 05.12.10].

Simon, H. (1995) A behavioural model of rational choice, Quarterly Journal of Economics, 69(1), 99-118.

Stroh, L.K., Northcraft, G.B., Neale, M.A. (2002) Organizational behaviour: A management challenge, $3^{\text {rd }}$ ed., Mahwah, NJ: Lawrence Erlbaum.

United Nations Development Programme (1996) Urban agriculture: food, jobs and sustainable cities. New York: UNDP.

Van Lill, C. (2000) A model of studying users' information needs and use. South African Journal of Library and Information Science, 67(1), 39-49.

Wesseler, G. and Brinkman, W. (2002) Bridging information gaps between farmers, policy makers, researchers and development agents. At: Agroforestry impacts on livelihoods in South Africa: Putting research in practice, Aventura Wambaths, South Africa, 20-24 May 2002. URL:

http://dlio.ctafotogallery.webfactional.com/static/eng/files/2hash/5f/5f02707e3091 cd0f20c4661930106d468602c618/Bridging_Information_Gaps_between_Farmers Policy-makers Researchers and Development Agents.pdf [accessed 05.12.10].

Wilson, T.D. (1981) On user studies and information needs, Journal of Documentation, 37(1), 3-15.

Wilson, T.D. and Walsh, C. (1996) Information behaviour: an interdisciplinary perspective. Sheffield: University of Sheffield, Department of Information Studies. URL: http://informationr.net/tdw/publ/infbehav/cont.html [accessed 05.12.10]. 


\section{Acknowledgement}

We acknowledge the Government of Sweden, which through the Swedish Development Agency (SIDA/sarec) provided financial support for this research. We also thank the study respondents and local leaders in the study area for their cooperation, without which this study would not have been accomplished. Logistical support by Makerere University is acknowledged.

\section{Open access and copyright}

Library and Information Research is an open access journal. A freely available copy of this paper may be downloaded from the journal's website:

http://www.cilipjournals.org.uk/lir

Copyright and associated moral rights in works published in Library and Information Research are retained by the author(s) but this paper may be used freely, with proper attribution, in educational and other non-commercial settings. 